\title{
Media and Communication Workers
}

National Cancer Institute

\section{Source}

National Cancer Institute. Media and Communication Workers. NCI Thesaurus. Code C122482.

The group of professions that include announcers, news analysts, reporters and correspondents, public relations specialists, writers and editors. 